\title{
KLAUSUL KUASA MUTLAK DALAM AKTA JUAL BELI TANAH DI KOTA PALOPO
}

\author{
Ashar Sinilele \\ Universitas Islam Negeri Alauddin Makassar
}

\begin{abstract}
Based on the provisions of Article 1813 of the Civil Code which states that the granting of power ends with the withdrawal of the power of attorney, if it is associated with the clause granting the power of attorney in a binding purchase agreement which is an absolute power or that can't be revoked, then it is clear that the clause is contrary to existing laws. This is also explained in Article 1814 of the Civil Code regarding the existence of the right of the grantor to withdraw his power of attorney if desired. Thus the absolute power clause is a deviation from the law. Based on the Instruction of the Minister of Home Affairs Number 14 of 1982, it is also clear that this violates regulations which are still in force. That absolute clausal agreements as applied a lot is a form of contradiction in the law so that it should need to be revised. For data collection this research was carried out at the Palopo City Notary Office regarding the land purchase agreement as regulated in the Civil Code.
\end{abstract}

Keywords: Deed, Buy and Sell, Absolute Power of Attorney.

\begin{abstract}
Abstrak
Berdasarkan ketentuan Pasal 1813 KUH-Perdata yang menyebutkan bahwa pemberian kuasa berakhir dengan ditariknya kembali kuasa penerima kuasa, jika dikaitkan dengan klausul pemberian kuasa pada perjanjian pengikatan jual beli yang merupakan kuasa mutlak atau kuasa yang tidak dapat dicabut kembali, maka jelas bahwa klausul tersebut bertentangan dengan undang-undang yang ada. Hal ini juga dijelaskan pada Pasal 1814 KUH-Perdata tentang adanya hak dari pemberi kuasa dapat menarik kembali kuasanya manakala dikehendaki. Dengan demikian klausul kuasa mutlak merupakan penyimpangan dari undangundang. Berdasarkan Instruksi Menteri Dalam Negeri Nomor 14 Tahun 1982 , jelas juga hal tersebut melanggar peraturan yang sampai saat ini masih berlaku. Bahwa perjanjian clausul mutlak sebagaimana banyak diterapkan merupakan suatu bentuk pertantangan di dalam undang-undang sehingga hal tersebut seharusnya perlu mendapat revisi. Untuk pengambilan data penelitian ini dilakukan di kantor Notaris Kota Palopo yang berkenaan tentang perjanjian jualbeli tanah sebagaimana yang diatur dalam KUH-Perdata.
\end{abstract}

Kata Kunci : Akta, Jual Beli, Kuasa Mutlak. 


\section{PENDAHULUAN}

Menurut Mac Iver dan Page, kebiasaan merupakan perikelakuan yang diakui dan diterima masyarakat. Apabila kebiasaan tersebut tidak semata-mata dianggap sebagai cara berperilaku saja, akan tetapi bahkan diterima sebagai norma pengatur, maka disebut kebiasaan tadi sebagai mores atau tata kelakukan. Tata kelakuan mencerminkan sifat hidup dan kelompok manusia yang dilaksanakan sebagai alat pengawas, secara sadar maupun tidak sadar oleh masyarakat terhadap anggota-anggotanya. ${ }^{1}$

Dalam perkembangan selanjutnya, khususnya pada saat sekarang ini di mana kegiatan manusia semakin berkembang, nyata terlihat bentuk-bentuk hubungan hukum dengan cara membuat suatu perjanjian, yang mana dalam perjanjian tersebut sering kali mencantumkan klausula kuasa sesuai dengan apa yang dikehendaki. ${ }^{2}$ Memang pemberian kuasa merupakan perbuatan hukum yang paling banyak dijumpai dalam masyarakat, selain itu pemberian kuasa adalah perbuatan yang mendasar sekali dan penting dalam proses hubungan hukum maupun bukan hubungan hukum, dalam hal seseorang menghendaki dirinya diwakili oleh orang lain untuk menjadi kuasanya, untuk melaksanakan segala sesuatu yang merupakan kepentingan sipemberi kuasa, dalam segala hal, termasuk dalam hubungan-hubungan dengan pihak-pihak lain selain kuasanya.

Secara teoritis, pemberian kuasa diatur dalam Pasal 35 Undang-Undang Republik Indonesia Nomor 14 Tahun 1970 tentang Ketentuan-ketentuan Pokok Kekuasaan Kehakiman, yang menjelaskan bahwa pemberian kuasa disebutkan secara tersirat dan konkritnya disebut sebagai bantuan hukum. Dengan mengutip pendapat dari K. Smith Dan D.J. Keenam, Santoso Poedjosoebroto berpendapat, bahwa bantuan hukum atau legal di diartikan sebagai yang sederhana, cepat dan biaya ringan. ${ }^{3}$ Pemberian kuasa juga diatur dalam Pasal 1792 sampai dengan Pasal 1819 Kitab Undang-Undang Hukum Perdata, atau dalam titel XVI Buku ke III. Adapun dalam Pasal 1792 KUH-Perdata disebutkan bahwa :

"Pemberian kuasa adalah suatu persetujuan dengan mana seorang memberikan

kekuasan kepada seorang lain, yang menerimanya, untuk atas namanya menyelenggarakan suatu urusan."

Pemberian kuasa dalam perkembangannya menjadi luas sekali, akan tetapi semua itu tidak akan dibahas dalam tulisan ini, hanya pemberian kuasa dalam praktek yang dituangkan dalam akta notaris yang berkembang dalam kehidupan masyarakat yang berkaitan dengan kepentingan masyarakat dalam melakukan

\footnotetext{
${ }^{1}$ Abdulhay Marhainis, Hukum Perdata Material, (PT. Pradnya Paramita, 1982). h. 69.

2 Ibid., h. 128.

${ }^{3}$ Ibid., h. 273.
} 
suatu perbuatan hukum jual beli khususnya mengenai bidang tanah. Akta tersebut yang dimaksud atau yang lebih dikenal dengan akta " Perjanjian Pengikatan Jual Beli “.

Ada beberapa macam pemberian kuasa yang umum dikenal oleh masyarakat, karena seringkali dijumpai dalam kehidupan bermasyarakat. Macam pemberian kuasa itu dapat ditinjau dari berbagai sebab. Berdasarkan sifat perjanjiannya, maka pemberian kuasa dapat merupakan pemberian kuasa umum, maupun pemberian kuasa khusus. Demikian pemberian kuasa tersebut dilakukan oleh penjual kepada pembeli, dengan ketentuan bahwa kuasa tersebut merupakan bagian yang tidak terpisahkan dari perjanjian pengikatan jual beli itu sendiri. Adapun pemberian kuasa mutlak khususnya terhadap tanah dalam akta perjanjian pengikatan jual beli yang pada hakekatnya adalah pengalihan hak tidak bertentangan dengan Pasal 37 jo.Pasal 38 jo.Pasal 39 PP 24 Tahun 1997 tentang Pendaftaran Peralihan dan Pembebanan Hak. Dalam Pasal 37 berbunyi sebagai berikut :

1) Peralihan hak atas tanah dan hak milik atas satuan rumah susun melaui jual beli, tukar menukar, hibah, pemasukan dalam perusahaan, dan perbuatan hukum pemindahan hak lainnya, kecuali pemindahan hak melalui lelang hanya dapat didaftarkan jika dibuktikan dengan akta yang dibuat oleh PPAT yang berwenang menurut ketentuan peraturan perundang-undangan yang berlaku.

2) Dalam keadaan tertentu sebagaimana yang ditentukan oleh Menteri Kepala Kantor Pertanahan dapat mendaftar pemindahan hak atas bidang tanah hak milik, yang dilakukan diantara perorangan Warga Negara Indonesia yang dibuktikan dengan akta yang tidak dibuat oleh PPAT, tetapi yang menurut kepala Kartor Pertanahan tersebut kadar kebenarannya dianggap cukup untuk mendaftar pemindahan hak yang bersangkutan.

Menurut ketentuan Pasal 38 berbunyi sebagai berikut:

1) Pembuatan akta sebagaimana yang dimaksud dalam Pasal 37 ayat (1) dihadiri oleh para pihak yang melakukan perbuatan hukum yang bersangkutan dan disaksikan oleh sekurang-kurangnya 2 orang saksi yang memenuhi syarat untuk bertindak sebagai saksi dalam perbuatan hukum itu.

2) Bentuk, isi dan cara pembuatan akta-akta PPAT diatur oleh Menteri. Dalam Pasal 39 berbunyi sebagai berikut:

PPAT menolak untuk membuat akta jika, untruk membuat akta:

a. Mengenai bidang tanah yang sudah terdaftar atau hak milik atas satuan rumah susun kepadanya tidak bisa disampaikan sertifikat asli hak yang 
bersangkutan atau sertifikat yang diserahkan tidak sesuai dengan daftardaftar yang ada di Kantor Pertanahan;

b. Mengenai daftar tanah yang belum terdaftar kepadanya tidak disampaikan:

1) Surat bukti hak sebagaimana dimaksud dalam Pasal 24 ayat (1) atau surat keterangan Kepala Desa/Kelurahan yang menyatakan bahwa yang bersangkutan menguasai bidang tanah tersebut sebagaimana dimaksud dalam Pasal 24 ayat (2); dan

2) Surat keterangan yang mengatakan bahwa bidang tanah yang bersangkutan belum bersertifikat dari kantor pertanahan, atau untuk tanah yang terletak di daerah yang jauh dari kedudukan kantor pertanahan, dari pemegang hak yang bersangkutan dengan dikuatkan oleh Kepala Desa/Kelurahan;

c. atau Salah satu atau para pihak yang akan melakukan perbuatan hukum yang bersangkutan atau salah satu saksi sebagaimana dimaksud dalam Pasal 38 tidak berhak atau tidak memenuhui syarat untuk bertindak demikian;

d. atau Salah satu pihak atau para pihak bertindak atas dasar suatu surat kuasa mutlak yang pada hakekatnya berisikan pernbuatan hukum pemindahan hak;atau

e. Untuk perbuatan hukum yang akan dilakukan belum diperoleh ijin pejabat atau instansi yang berwenang, apabila ijin tersebut diperlukan menurut peraturan perundang-undangan yang berlaku; atau

f. Obyek perbuatan hukum yang bersangkutan sedang dalam sengketa mengenai dan fisik dan atau data yuridisnya; atau.

g. Tidak dipenuhi syarat lain atau dilanggar larangan yang ditentukan dalam peraturan perundang-undangan yang bersangkutan. Ketentuan tersebut tidak diatur dalam Kitab Undang-Undang Hukum Perdata, namun diakui di dalam lalu lintas bisnis dimasyarakat, hal ini merupakan suatu perikatan yang muncul dari perjanjian, yang diatur dalam Pasal 1338 Kitab UndangUndang Hukum Perdata, yang mengakui adanya kebebasan berkontrak, dengan pembatasan bahwa perjanjian itu tidak boleh bertentangan dengan peraturan perundangan dan harus didasari dengan itikat baik. ${ }^{4}$

${ }^{4}$ Kansil, dkk. Modul Hukum Perdata termasuk Azas-Azas Hukum Perdata, (Jakarta: PT. Pradnya Paramita, 2006). h. 196. 


\section{METODE PENELITIAN}

Pengambilan data ini dilakukan di kantor Notaris di Kota Palopo yang berkenaan tentang perjanjian jual-beli tanah sebagaimana yang diatur menurut KUH-Perdata.

Data primer adalah data yang diperoleh langsung dari sumber pertama, yakni dari masyarakat yang telah dipilih dan ditetapkan sebagai responden (penjual dan pembeli) melalui pendekatan sosiologis., Data sekunder adalah data yang bersumber dari peraturan Perundang-Undangan, referensi lainnya sebagai bahan rujukan yang ada hubungannya dengan objek kajian.

Teknik yang digunakan adalah Melakukan wawancara langsung kepada responden dalam hal pembeli dan penjual tanah untuk diolah dan dianalisis. Kepustakaan yaitu dilakukan dengan cara mengkaji secara substansial normanorma hukum yang berkenaan dengan itikad baik dalam jual-beli.

\section{PEMBAHASAN}

\section{A. Klausul kuasa mutlak dalam jual beli tanah di Kota Palopo.}

Seperti telah dijelaskan diatas, menurut macam atau jenis pemberian kuasa dilihat dari sifat perjaniiannya,maka pemberian kuasa dapat dibedakan yaitu pemberian kuasa umum dan pemberian kuasa khusus. Adapun yang dimaksud dengan pemberian kuasa dijelaskan pada Pasal 1192 KUH-Perdata, yaitu : "Pemberian kuasa adalah suatu persetujuan dengan mana seorang memberikan kekuasaan kepada seorang lain, yang menerimanya untuk atas namanya menyelenggarakan suatu urusan." Pasal 1792 KUH-Perdata tersebut menunjukkan bahwa sifat pemberian kuasa tidak lain dari mewakilkan atau perwakilan (Vertegenwoordiging). Pemberian kuasa sebagai wakil, yang dibuat melalui persetujuan selalu disebut kuasa atau volmacht. Pada dasarnya kuasa inilah yang menjadi tujuan dari persetujuan pemberian kuasa tersebut yang kemudian di masukkan sebagai klausul dalam suatu akta notariil . Dengan kekuasaan dari pemberian kuasa tersebut, maka penerima kuasa menjadi dapat berwenang melakukan $\mathrm{t}$ indakan atau perbuatan hukum untuk kepentingan dan atas nama pemberi kuasa. Berdasarkan kuasa tersebut ia dapat bertindak atas dasar volmacht dari pihak pemberi kuasa untuk mengurus dan menjalankan segala tindakan yang berkenaan dengan obyek dalam perjanjian. Namun demikian perlu diperhatikan, bahwa pemberian kuasa tersebut hanya meliputi tindakan pengurusan saja, dan hal ini tersirat pada Pasal 1792 KUHPerdata dan ditegaskan pada Pasal 1797 bahwa sipenerima kuasa tidak boleh melakukan sesuatu apapun yang melampaui batas kuasanya. Maksudnya disini adalah bahwa penerima kuasa tidak diperbolehkan melakukan segala perbuatan hukum yang menurut hukum 
hanya dapat dilakukan oleh si pemberi kuasa dalam hal ini adalah pemilik / pemegang haknya. Sedangkan jika dikaitkan dengan Pasal 1813 KUH-Perdata tentang berakhirnya, pemberian kuasa menyebutkan pemberian kuasa berakhir :

1. dengan ditariknya kembali kuasanya sipenerima kuasa;

2. dengan pemberitahuan penghentian kuasanya oleh sipenerima kuasa;

3. dengan meninggalnya, pengampuannya atau pailitnya pemberi kuasa atau

si penerima kuasa maka pemberian kuasa yang dimaksud dalam Pasal 1792 KUH- Perdata tidaklah dapat dilepaskan dari isi Pasal 1813 tersebut. Artinya bahwa apabila unsur-unsur yang terdapat dalam Pasal 1813 KUH-Perdata tersebut terpenuhi maka perjanjian pemberian kuasa yang dibuat berakibat tidak berkekuatan hukum lagi. Demikian apabila perjanjian pemberian kuasa tersebut dimasukkan sebagai klausula dalam suatu perjanjian pokok, misalnya dalam masalah ini , yaitu perjanjian jual beli , yang dikenal dengan perjanjian pengikatan jual beli, maka hal ini tergantung dari pada sah atau tidaknya perjanjian pokok tersebut . Artinya apabi la perjanjian pokok-nya tidak sah atau batal demi hukum, maka klausul pemberian kuasa menjadi tidak berkekuatan hukum.Sebaliknya apabila perjanjian pokok-nya sah, maka klausul pemberian kuasa menjadi berkekuatan hukum, dengan syarat klausul pemberian kuasa tidak bertentangan dengan peraturan perundangan yang berlaku, tetapi dalam hal ini jika klausul pemberian kuasa tersebut bertentangan dengan peraturan perundangan-undangan, maka perjanjian pokoknya tetap sah, hanya klausul kuasanya yang tidak berkekuatan hukum. Dalam masalah ini, mengenai klausul pemberian kuasa mutlak . Seperti dinyatakan dalam Instruksi Menteri Dalam Negeri Nomor 14 Tahun 1982, yang dimaksud dengan "Kuasa Mutlak" adalah kuasa yang didalamnya mengandung unsur tidak dapat ditarik kembali oleh pemberi kuasa.

Namun dalam hal ini, kuasa mutlak itu sendiri tidak ada peraturan khusus yang mengaturnya. Akan tetapi akibat dari Pasal 1334 ayat (1) KUH-Perdata yang menyebutkan bahwa semua perjanjian yang dibuat secara sah berlaku sebagai undang-undang bagi mereka yang membuatnya. Pasal ini lebih dikenal sebagai dasar dari kebebasan berkontrak. Sekarang yang menjadi pertanyaan, apakah meskipun hal tersebut merupakan kebebasan dari Para pihak yang membuatnya, tidak bertentangan dengan pertauran perundang-undangan yang lain, misalnya Pasal 1813 KUH Perdata tentang berakhirnya pemberian kuasa (khususnya Pasal 1813 ayat (1)) dan Instruksi Menteri Dalam Negeri Nomor 14 Tahun 1982 tentang Larangan Penggunaan Kuasa Mutlak Sebagai Pemindahan Hak atas Tanah.

Berdasarkan ketentuan Pasal 1813 KUH-Perdata yang menyebutkan bahwa pemberian kuasa berakhir dengan ditariknya kembali kuasa sipenerima kuasa, jika dikaitkan dengan klausul pemberian kuasa pada perjanjian pengikatan jual beli

\section{7}


yang merupakan kuasa mutlak atau kuasa yang tidak dapat dicabut kembali, maka jelas bahwa klausul tersebut bertentangan dengan undang-undang yang ada. Hal ini juga dijelaskan pada Pasal 1814 KUH-Perdata tentang adanya hak dari pemberi kuasa dapat menarik kembali kuasanya manakala dikehendaki. Dengan demikian klausul kuasa mutlak merupakan penyimpangan dari undang-undang 23 Berdasarkan Instruksi Menteri Dalam Negeri Nomor 14 Tahun 1982 tersebut diatas, jelas juga hal tersebut melanggar peraturan yang sampai saat ini masih berlaku.

Namun demikian jika Instruksi Menteri Dalam Negeri Nomor 14 Tahun 1982 tentang Larangan Penggunaan Kuasa Mutlak Sebagai Pemindahan Hak Atas Tanah, apabila dikembalikan pada undang-undang yaitu Pasal 1792 KUH-Perdata tentang pemberian kuasa (Last geving), khususnya pada Pasal 1813 KUH-Perdata (serta Instruksi Mendagri No.14 Tahun 1982 juga berdasarkan PP 24 Tahun 1997), tentang berakhirnya suatu pemberian kuasa, apabila dikaitkan dengan Pasal 1338 KUH-Perdata tentunya "para pihak dapat memperjanjikan". Demikian kebebasan para pihak untuk membuat perjanjian dijelaskan oleh salah satu Pengantur terkemuka dari aliran Hukum Alam, yaitu Hugo Grotius yang berpendapat bahwa : Hak untuk mengadakan perjanjian adalah salah satu hakhak asasi manusia". dan ia beranggapan bahwa suatu kontrak adalah suatu tindakan suka reIa dari seseorang dimana ia berjanji sesuatu kepada orang lain dengan maksud bahwa orang lain itu akan menerimanya.

\section{B. Praktek Klausul Kuasa Mutlak Dalam perjanjian Jual Beli Tanah di Kota Palopo}

Berkaitan dengan Akta Perjanjian Pengikatan Jual Beli, yang mana pada akta tersebut terdapat 2 (dua) kemungkinan yaitu :

1. Akta Perjanjian Pengikatan Jual Beli tersebut tidak dipergunakan, karena pihak pertama turut hadir dihadapan Pejabat Pembuat Akta Tanah yang berwenang. Dalarn hal ini, berarti perjanjian pemberian kuasa mutlak tidak perlu dijalankan ;

2. Akta Perjanjian Pengikatan Jual Beli dipergunakan. Hal ini karena pihak pertama tidak dapat hadir untuk membantu pihak kedua, dan pihak kedua bertindak berdasarkan perjanjian pemberian kuasa yang dijadikan sebagai klausul dalarn aktaPerjanjian Pengikatan Jual Beli tersebut.

Disinilah peran Akta Perjanjian Pengikatan Jual Beli dimana klausul perjanjian pemberian kuasa dapat dijalankan atau tidak. Akan tetapi dalam permasalahan disini mengenai mutlak dikaitkan dengan Akta PPJB digunakan sebagai dasar 
bertindaknya, perlu diperhatikan bahwa tidak semua pemberian kuasa pada pihak lain beralih kepada penerima kuasa.

Hal ini dibatasi dengan Instruksi Menteri Dalam Negeri Nomor 14 Tahun 1982, melarang pejabat-pejabat kuasa Agraria untuk melayani penyelesaian status hak atas tanah yang menggunakan surat kuasa mutlak sebagai bukti pemindahan hak (yang dimaksud adalah langsung dengan surat kuasa mutlak tanpa, melalui perbuatan hukum dihadapan Pejabat Pembuat Akta Tanah). Seperti telah ditegaskan dalam Pasal 1792 KUH-Perdata tentang pemberian kuasa, dimana pemberian kuasa disini hanya meliputi tindakan pengurusan saja.

Seperti telah diterangkan diatas, bahwa dilihat dan sebab-sebab mengapa dipilihnya perbuatan hukum pengalihan hak atas tanah dengan suatu pernbuatan Akta Perjanjian Pengikatan Jual Beli, yang dapat dikatagorikan menjadi 3 (tiga) kelompok, yaitu :

1. Pembayaran atas jual beli tersebut telah dilunasi oleh pihak pembeli kepada pihak pertama, dan pihak pertama telah menerima sertifikat pernbayaran tersebut, tertulis) akan tetapi (syarat formal sebagai bukti pemilikan yang sah sesuai dengan UUPA, masih dalam proses permohonan hak, dan permohonan tersebut sudah sampai pada Kanwil Pertanahan;

2. Pembayaran atas jual beli tersebut belum dilunasi oleh pihak pembeli dengan angsuran karena sertifikat sebagai bukti kepemilikan hak atas tanah belum terpenuhi;

3. Pembayaran atas jual beli dilakukan dengan angsuran, meskipun sertifikat sudah ada dan sudah atas nama pihak pertama. Dalam penulisan ini, mengenai pemberian kuasa mutlak dalam perjanjian pengikatan jual beli, seperti telah diterangkan diatas berkaitan dengan dan atau bersumber pada perjanjian pokok, yang dalam akta perjanjian pengikatan jual beli tersebut terdapat pada bagian recital/premise, misalnya diterangkan bahwa Pihak pertama menerangkan dalam akta ini telah mengikatkan diri untuk menjual dan menyerahkan kepada pihak kedua yang menerangkan telah mengikatkan dirinya sendiri untuk membeli dan menerima penyerahan dari pihak pertama Jual beli ini menurut para pihak akan dilakukan dengan harga sebesar Rp., --- jumlah uang mana menurut keterangan pihak pertama telah diterima seluruhnya Selanjutnya jual beli ini menunut keterangan para pihak dilakukan apabila sertifikat hak atas tanah tersebut telah dikeluarkan oleh instansi yang berwenang dan tertulis atas nama pihak pertama dengan syarat-syarat dan aturan yang ditetapkan dalarn formulir Akta Jual Beli Pejabat Kuasa yang tersebut dalam akta ini merupakan bagian yang tidak terpisahkan dan pengikatan jual beli ini. 
Jadi yang dimaksud dengan perjanjian pokoknya disini adalah pengikatan jual belinya itu sendiri. Dan segera setelah perjanjian pokoknya terpenuhi maka kuasa mutlak tersebut dengan sendirinya berakhir (dalam hal Surat Kuasa Membebankan Hak Tanggungan) atau dapat dijalankan (dalam hal Perjanjian Pengikatan Jual Beli).

Maksudnya disini, manakala telah sampai pada waktunya (perjanjian pokoknya terpenuhi, yaitu sertifikat sudah ada atas nama pihak pertama/penjual), sedangkan pihak pertama (Penjual) "telah menerima semua hak-haknya" akan tetapi lalai atau tidak dapat memenuhi kewajibannya membantu pihak kedua (Pembeli) untuk pengurusan pembuatan akta jual beli, demikian agar dapat dilakukan pendaftaran di Kantor Pertanahan setempat, sehingga sertifikat dapat dibalik nama keatas nama pihak pembeli, maka dengan kuasamutlak tersebut pihak pembeli dapat menghadap kepada pejabat yang berwenang dalam hal ini Pejabat Pembuat Akta Tanah dengan bertindak dalam dua kapasitas, yaitu pertama bertindak sebagai pihak penjual dengan dasar akta perjanjian pengikatan jual beli tersebut dan yang kedua sebagai pihak pembeli sendiri. Sehingga hal ini tidak bertentangan dengan kuasa mutlak yang dibuat untuk menghindari ketentuan-ketentuan UUPA jo. PP.No.24 Tahun 1997.

Dari akta-akta jual beli yang dibuat oleh seorang PPAT, berdasarkan penulis survei melalui wawancara, maka sebagian besar seorang PPAT dapat menerima pembuatan akta jual beli berdasarkan akta perjanjian pengikatan jual beli yang mengandung unsur kuasa mutlak. Demikian mengenai akta jual beli tersebut, oleh seorang PPAT dapat dijadikan bukti untuk melakukan pendaftaran di Kantor Pertanahan setempat, dan oleh Kepala Kantor Pertanahan diterima dan didaftarkan sebagai pemindahan hak atas tanah. Hal ini terbukti bahwa sertifikat yang atas nama pihak pertama (penjual) dapat diubah menjadi atas nama pihak kedua (pembeli).

Kedua dan ketiga : Pembayaran atas obyek perjanjian dilakukan dengan angsuran, karena syarat formal tertulis belum terpenuhi ataupun sudah terpenuhi. Sebelumnya perlu ditegaskan, bahwa pemberian kuasa mutlak disini dilakukan oleh pihak penjual/pihak pertama kepada pihak pembeli/pihak kedua.

Demikian pemberian kuasa mutlak disini ditujukan untuk kepentingan penerima kuasa, sehingga dengan ini kewajiban-kewajiban dan pihak pembeli/pihak kedua selaku penerima kuasa harus sudah dilaksanakan dan dengan ini hak dari pihak penjual/pihak pertama selaku pemberi kuasa segera dapat terpenuhi. Artinya pihak penjual/pihak pertama sekarang hanya mempunyai kewajiban dan pihak pernbeli/pihak kedua hanya menunggu haknya dapat dilaksanakan atau terpenuhi. Dan apa yang diuraikan diatas, maka dalam kedua 
kelompok ini, apabila dalam pembuatan akta perjanjian pengikatan jual beli dicantumkan mengenai kuasa mutlak, dapat berakibat timbulnya berbagai konflik.

Adapun konflik tersebut dapat berupa :

1. Ketidakseimbangan hak dan kewajiban dari para pihak. Seperti diterangkan diatas, bahwa pemberian kuasa mutlak ditujukan untuk kepentingan pihak penerima kuasa dalam hal ini pihak pembeli. Permasalahannya sekarang bagaimana dengan kepentingan pihak penjual, dimana ia belum menerima semua haknya, sedang pihakpembeli dengan kekuatan kuasa yang diterimanya dapat melakukan segala tindakan terhadap obyek perjanjian dalam perbuatan hukum perjanjian pengikatan jual beli tersebut. Bagaimana apabila pihak pembeli tidak dapat memenuhi kewajibannya melunasi pembayaran atas obyek jual beli tersebut, hal ini dapat merugikan pihak penjual;

2. Penyalahgunaan klausul pemberian kuasa yang yang tidak dapat dicabut kembali. Dengan kekuatan pemberian kuasa, walaupun penerima kuasa belum rnelunasi pembayaran atas jual beli tersebut, dapat melakukan tindakan pemilikan dan tindakan pengurusan tanpa persetujuan dan pemberi kuasa dalam hal ini penjual, dan ini sangat merugikan pihak penjual, karena pihak penjual tidak dapat berbuat apa-apa. Dan hal ini merupakan perbuatan melanggar hukum dan menerima kuasa karena telah melampaui batas-batas kuasanya.Tindakan yang diambil oleh seorang Notaris-PPAT dalam menangani peralihan hak atas tanah, berdasarkan pertirnbangan, bahwa selain sebagai pejabat pembuat akta tanah juga sebagai penasehat hukum. Oleh karena itu dalarn praktek, pada saat menghadapi kasus-kasus tersebut, sebagai penasehat hukum, memberikan alternatif-alternatif tindakan yang dapat ditempuh adalah sebagai berikut :

a. Agar segera melunasi pembayarannya atau melunasi utangnya yang nantinya diperhitungkan sebagal harga jual tanah tersebut. Setelah sertifikat diperoleh, maka keduanya datang menghadap kepada PPATNotaris untuk melakukan transaksi jual beli.

b. Agar menunggu sertifikat terbit atas nama pihak penjual, kemudian keduanya datang menghadap ke PPATNotaris untuk melakukan transaksi akta jual beli.

c. Dengan menunggu sertifikat diperoleh atas nama pihak penjual (sertifikat dalam proses permohonan hak dan sudah sarnpai kanwil Pertanahan), maka dilakukan perbuatan hukum dengan membuat akta Perjanjian Pengikatan Jual Beli, dengan syarat pembayaran sudah dilunasi. 
Disinilah terlihat peran PPAT-Notaris terhadap kasus-kasus yang dihadapi, tentunya tetap memperhatikan dan segi positif maupun negatif, karena tindakan yang diambilnya sekarang, tidaklah selesai sampai disitu saja, tatapi dapat pula berakibat dimasa mendatang. Dalam hal ini mengenai tindakan yang diambil berupa pembuatan akta perjanjian pengikatan jual beli,.

\section{PENUTUP}

\section{A. Kesimpulan}

Berdasarkan pembahasan diatas maka, disimpulkan sebagai berikut:

1) Bahwa perjanjian clausul mutlak sebagaimana banyak diterapkan merupakan suatu bentuk pertantangan di dalam undang-undang sehingga hal tersebut seharusnya perlu mendapat revisi.

2) Pada umumya dalam transaksi jual beli harus dilaksanakan di hadapan notaris, agar dapat mempunyai kepastian hukum atas hak tersebut.

B. Saran

1) Senantiasa melakukan tranksaksi di hadapan notaris dengan memperlihatkan bukti-bukti outentik.

2) Tidak mudah melakukan transaksi jual beli tanah dengan di bawah tangan. 


\section{DAFTAR PUSTAKA}

Abdulhay Marhainis. Hukum Perdata Material. PT. Pradnya Paramita, 1982.

Amiruddin, dkk. Pengantar Metode Penelitian Hukum. Jakarta: PT. Raja Gratindo Persada, 2004.

Effendi Perangin. Hukum Agraria di Indonesia Suatu Telaah dari Sudut Pandang Praktisi Hukum, Jakarta: Rajawali, 1989, h. 195.

1985.

Hartono Soerjopratiknjo. Aneka Perjanjian Jual-Beli. Yogyakarta: PT. Mustika Wikasa, 1994.

Kansil, dkk, Modul Hukum Perdata termasuk Azas-Azas Hukum Perdata, Jakarta: PT. Pradnya Paramita, 2006.

R. Soerjatin. Beberapa Soal Pokok Hukum Perdata dan Hukum Dagang. Jakarta: Pradnya Paramita, 1983.

R. Soesilo. Kitab Undang-Undang Hukum Perdata. Jakarta: Wipres, 2007.

R. Subekti. Aneka Perjanjian, Cetakan IV, Bandung: Alumni, 1984.

--------. Pokok-Pokok Hukum Perdata. Jakarta: PT. Intermasa, 1985.

----------. Perbandingan Hukum Perdata. Jakarta: Pradnya Paramita, 1993.

--------. Pokok-Pokok Hukum Perdata. Jakarta: PT. Intermassa, 1996.

R. G. Kartasapoetra. Hukum Tanah - Jaminan UUPA Bagi Keberhasilan Pendayagunaan Tanah. Jakarta: PT. Bina Aksara, 1985.

Salim, H. S. Hukum Kontrak - Teori dan Teknik Penyusunan Kontrak. Jakarta: Sinar Grafika, 2006.

Soedibyo. Teknik Konservasi Sumber Daya Alam dan Lingkungan. Bogor: Rimba Indonesia, 1988.

Soerjono Soekanto. Pengantar Penelitian Hukum. Jakarta: Universitas Indonesia Press, 1986

Supardi. Hukum Lingkungan di Indonesia. Jakarta: Sinar Grafika, 2006.

Suparmoko. Ekonomi Sumber Daya Alam dan Lingkungan. (suatu pendekatan teoritis). Yogyakarta: BPFE, 1994.

Urip Santoso. Hukum Agraria dan Hak-Hak Atas Tanah. Jakarta: Kencana Prenada Media Group, 2007.

-. Undang-Undang Pokok No. 5 Tahun 1960 Tentang Pertaturan

Dasar Pokok-Pokok Agraria. Jakarta: Kencana Prenada Media Group, 2005.

Wirjono Prodjodikoro. Azas-Azas Hukum Perjanjian. Bandung: Sumur, 1973. Azas-Azas Hukum Perdata. Bandung: PT. Bali Bandung, 1990. 